\title{
TATA LETAK BUKU TERJEMAHAN KOMUNIKASI INTERPERSONAL BERDASARKAN GAYA SELINGKUNG PENERBIT SALEMBA
}

\author{
Ariesti Putri Perdana, Noor Riyadhi \\ Program Studi Penerbitan, Jurusan Penerbitan, \\ Politeknik Negeri Media Kreatif Jakarta
}

\begin{abstract}
Producing translation manuscripts has a different level of complexity of the local paper. Not only focusing on the content, the layout must also be observed more because it is crucial to the making of a book. The methods used to identify the problems and to get the solutions are a literary research, observation, and interview. Based on the results of discussion, there are several obstacles in layouting the translation book "Komunikasi Interpersonal". How to deal with the obstacles is to pay more attention to the layout, the principles and elements due to the difference housestyles between the Cengage Publisher (source text) and Publisher Salemba (target text).
\end{abstract}

Keywords: translation book, layout, housestyle

\section{PENDAHULUAN}

Penerbitan adalah industri yang berkonsentrasi memproduksi dan memperbanyak sebuah literatur dan informasi yang dapat dinikmati publik. Bahan bakunya adalah naskah yang dihasilkan oleh penulis dan kemudian diolah oleh penerbit. Namun, penerbit tidak boleh berbuat sekehendaknya dengan naskah tersebut. Penerbit perlu memperhatikan norma-norma tertentu yang mencerminkan pendapat kolektif dalam perusahaan mengenai peranan sosial, ekonomis, edukatif, dan kultural yang akan dipegang, agar dapat dihasilkan terbitan yang berkualitas.

Jika ditinjau lebih lanjut, penerbit dibedakan menjadi tiga, yaitu penerbitan umum, ilmiah, dan pendidikan atau edukatif. Dalam penerbitan terdapat tiga kegiatan utama, yaitu praproduksi, produksi, dan pemasaran. Penggarapan naskah menjadi produk yang siap dibeli pembaca merupakan proses yang cukup memakan waktu dan kerja intensif. Oleh karena itu, diperlukan suatu sistem yang baik dalam prosesnya. Pada proses praproduksi, terdapat proses naskah masuk yang kemudian dilakukan proses penyuntingan dan tata letak atau biasa disebut layout, sebelum akhirnya dicetak dan dipasarkan kepada pembeli.

Tata letak merupakan salah satu proses atau tahapan kerja dalam desain dan dalam perkembangannya, sudah sangat meluas dan melebur dengan definisi desain itu sendiri. Media dengan ukuran dan bentuk 
yang berbeda tentu saja penerapan tata letaknya pun berbeda. Sebuah tata letak sangat berpengaruh pada media cetak, dalam hal ini adalah buku. Selain dilihat dari konten, sebuah buku juga harus menyajikan desain sampul dan tata letak yang baik pula agar terlihat rapi dan nyaman dibaca. Hal tersebut tentu sangat berpengaruh pada kualitas buku secara keseluruhan.

Tata letak juga didasari oleh gaya selingkung sebuah penerbit, karena setiap penerbit pasti memiliki gaya selingkung yang berbeda, untuk dapat membedakan penerbit yang satu dengan yang lain. Selain dilihat dari segi ketatabahasaan, juga dilihat dari segi visual, seperti desain sampul, tata letak, dan sebagainya. Sebuah desain yang baik pasti membuat pembaca tertarik untuk melihat, kemudian berkeinginan untuk membaca, dan akhirnya membeli. Oleh karena itu, peran sebuah desain juga sangat penting dalam sebuah buku, di samping konten dari buku itu sendiri.

Selama mengikuti kegiatan Praktik Industri (PI) di Penerbit Salemba, penulis ditempatkan bekerja di Bagian Produksi dan Penerbitan sebagai desainer tata letak. Penulis membuat tata letak buku terjemahan dan buku lokal, tetapi penulis lebih berkonsentrasi pada buku terjemahan. Buku terjemahan memiliki tingkat kerumitan yang lebih tinggi dibanding buku lokal. Hal tersebut yang mendasari penulis ingin mengangkat topik mengenai tata letak buku terjemahan di Penerbit Salemba.

Buku tersebut adalah buku terjemahan yang dalam bahasa aslinya adalah "Interpersonal Communication" yang ditulis oleh Julia T. Wood dan dari penerbit Cengage yang memang sudah bekerjasama dengan Penerbit Salemba. Pembuatan tata letaknya dibuat berdasarkan buku aslinya, tetapi tetap disesuaikan dengan gaya selingkung penerbit Salemba dan kreativitas dari desainer. Masalahmasalah yang terkait dalam proses pembuatan buku terjemahan tersebut menjadi bahasan dalam Tugas Akhir ini yang berjudul, "Tata Letak Buku Terjemahan Komunikasi Interpersonal Berdasarkan Gaya Selingkung Penerbit Salemba".

Menurut Marshall Lee (1980: 9), sesungguhnya desain adalah nama yang diberikan pada pemecahan masalah dalam bidang tertentu, yang di antaranya adalah pembuatan buku. Jika proses tiga tahap tidak dilaksanakan, hasilnya tidak bisa dikatakan sebagai desain. Tiga tahap tersebut adalah:

1 Analisis terhadap masalah

2 Pertimbangan atas kemungkinan pemecahan

3 Pilihan bagi pemecahan yang paling baik

Dari uraian mengenai desain tersebut, dapat disimpulkan bahwa desain adalah rancangan visual yang mengandung pemecahan masalah yang berkaitan dengan medianya.

Menurut Andrew Haslam dalam bukunya "Book Design" 
(2006: 9), Book: A portable container consisting of a series of printed and bound pages that preserves, announces, expounds, and transmits knowledge to a literate readership across time and space. Dapat disimpulkan dari kutipan tersebut bahwa buku adalah sesuatu yang terdiri atas serangkaian halaman yang dicetak dan terikat, yang berfungsi melindungi, mengumumkan, menguraikan, dan menyampaikan pengetahuan untuk pembaca agar dapat melintasi ruang dan waktu.

Buku berfungsi untuk menyampaikan informasi berupa cerita, pengetahuan, laporan, dan lain-lain. Buku dapat menampung banyak sekali informasi, tergantung jumlah halaman yang dimiliki. Sebagian besar elemen-elemen tata letak digunakan dalam buku. Pada umumnya elemen terbanyak adalah teks isi, maka perlu perhatian khusus dalam memilih dan menatanya. Penjilidan buku merupakan keharusan agar lembar-lembar kertasnya tidak tercerai-berai.

Sebuah buku memiliki bagian-bagian yang disebut anatomi buku. Menurut Iyan $\mathrm{Wb}$, dalam bukunya, Anatomi Buku (2007) dipaparkan bahawa anatomi buku adalah sebagai berikut:

1. Sampul Buku terdiri atas (a) sampul depan, (b) sampul belakang, (punggung buku).

2. Halaman Pendahulu (Preliminaries) terdiri atas (a) halaman judul, (b) hak cipta (copyright), (c) kata pengantar, (d) prakata, (e) daftar isi.

3. Halaman Isi terdiri atas (a) judul bab, (b) penomoran bab, (c) penomoran teks, (d) judul lelar, (e) catatan kaki.

4. Halaman Penyudah (Postliminary) terdiri atas (a) lampiran, (b) indeks, (c) daftar pustaka, (d) biografi penulis.

Standar ukuran kertas yang digunakan di seluruh dunia (kecuali di Amerika dan Kanada) termasuk di Indonesia adalah ISO 216. Standar ini menggunakan rasio 1 banding 1,4142 untuk ukuran lebar banding panjang kertas. Rasio ini diperkenalkan pertama kali oleh seorang peneliti Jerman yaitu George Lichtenberg pada tahun 1786. Standar ISO 216 mempunyai tiga seri, yaitu A, B, dan C yang masingmasing ukuran ditandai dengan angka di belakang, misalnya seri A0, A1, A2, A3, A4, A5, A6, A7.

Menurut Surianto Rustan dalam bukunya, "Layout Dasar dan Penerapannya", ia mengatakan bahwa tujuan utama tata letak adalah menampilkan elemen gambar dan teks agar menjadi komunikatif dalam sebuah cara yang dapat memudahkan pembaca menerima informasi yang disajikan. Pembuatan tata letak membutuhkan perencanaan, keakuratan, dan kreativitas di dalam menempatkan unsur-unsur penyusun materi sebuah media.

Dalam bukunya, "Pengantar Desain Komunikasi Visual" (2006: 277-286), Adi Kusrianto menjelaskan dalam desain diketahui ada 5 (lima) prinsip utama seperti 
yang dikatakan oleh Tom Lincy dalam bukunya "Design Principle for Desktop Publishing”. Lima prinsip tersebut adalah:

1. Proporsi (proportion): kesesuaian antara ukuran halaman dengan isinya.

2. Keseimbangan (balancing): pengaturan penempatan elemenelemen yang ada dalam sebuah halaman. Keseimbangan dihasilkan dari keselarasan beberapa elemen objek sehingga secara visual akan tampak seimbang. Ada dua macam keseimbangan, yaitu keseimbangan formal atau simetris dan keseimbangan informal atau tidak simetris. Keseimbangan formal biasanya digunakan untuk menata letak elemen grafis agar terkesan rapi dan formal sedangkan keseimbangan informal memiliki tampilan yang tidak simetri.

3. Kontras (contrast): fokus yang ditonjolkan. Masing-masing elemen di tiap halaman harus ada yang dominan, misalnya dapat menonjolkan headline, ilustrasi atau foto, ataupun white space.

4. Irama (rhythm): pola perulangan yang menimbulkan format untuk diikuti. Penggunaan pola warna ataupun motif yang diulang dengan irama tertentu merupakan salah satu prinsip penyusunan tata letak.

5. Kesatuan (unity): hubungan antara elemen-elemen desain yang semula berdiri sendiri serta memiliki ciri sendiri yang disatukan menjadi sesuatu yang baru dan memiliki fungsi baru yang utuh.

Dalam bukunya, "Layout Dasar dan Penerapannya" (2008), Surianto Rustan mengatakan bahwa elemen-elemen teks dengan fungsinya masing-masing saling bekerjasama satu dengan yang lainnya. Secara umum tujuan utama ialah menyampaikan informasi dengan lengkap dan tepat. Tiap media memiliki elemen tata letak yang berbeda. Beberapa elemen yang umum terdapat pada sebuah buku adalah sebagai berikut:

1. Elemen Teks

Umumnya elemen terbanyak yang terdapat pada tata letak adalah teks. Oleh sebab itu, agar tampilannya menarik dan nyaman untuk dibaca, perlu dilakukan penataan letak yang tepat. Berikut ini elemen- elemen teks yang terdapat pada tata letak pada buku secara umum:

a. Judul

Beberapa kata singkat yang mengawali sebuah artikel. Dari segi ukuran harus diperbesar dan pemilihan jenis huruf harus berbeda dari elemen yang lain, agar menarik perhatian pembaca. Ukuran huruf untuk judul dari 18 pt hingga 36 pt.

b. Deck

Gambaran singkat tentang topik yang dibicarakan di tubuh tulisan. Fungsi deck sebagai pengantar sebelum pembaca membaca tubuh 
tulisan. Ada tidaknya deck dan penataannya dipengaruhi oleh luas area halaman yang tersedia. Ukuran huruf lebih kecil dari judul lebih besar dari judul, berkisar antara 12 pt hingga $16 \mathrm{pt}$.

c. Bodytext

Isi atau naskah atau artikel merupakan elemen pada tata letak yang paling banyak memberikan informasi terhadap topik bacaan tersebut. Ukuran huruf untuk bodytext biasanya menggunakan $10 \mathrm{pt}$ hingga $11 \mathrm{pt}$.

d. Subjudul

Bagian-bagian dari sebuah judul. Berfungsi agar pembaca dapat lebih mudah untuk memahami naskah, karena tidak terlalu luas seperti judul.

e. Caption

Keterangan singkat yang menyertai elemen visual dan inzet. Jenis hurufnya berbeda dan ukurannya pun lebih kecil dari teks isi.

f. Callouts

Pada dasarnya sama dengan caption, kebanyakan menyertai elemen visual yang memiliki lebih dari satu keterangan. Pada diagram, callouts memiliki garis-garis yang menghubungkannya dengan bagian-bagian dari elemen visualnya.

g. Initial Caps

Huruf awal yang berukuran besar dari kata pertama pada paragraf dan apat juga berfungsi sebagai penyeimbang komposisi suatu tata letak.

h. Indent

Baris pertama paragraph menjorok masuk ke dalam, sedangkan hanging indent adalah kebalikannya; baris pertama tetap pada posisi, sedangkan baris-baris dibawahnya menjorok masuk ke dalam.

i. Lead Line

Beberapa kata pertama atau seluruh kata di baris paling awal pada tiap paragraf yang dibedakan atribut hurufnya.

j. Spasi Antarparagraf

Untuk membedakan paragraf yang satu dengan yain lainnya. Antar paragraf diberi spasi.

k. Header dan Footer

Header adalah area diantara sisi atas kertas dan margin atas. Footer adalah area diantara sisi bawah kertas dan margin bawah. Header dan footer bisa berisi running head, catatan kaki, nomor halaman, dan informasi lainnya.

1. Running Head

Judul buku, bab atau topik yang sedang dibaca dan informasi lainnya yang berulang-ulang ada pada setiap halaman dan posisi tidak berubah.

m. Catatan Kaki

Berisi detail informasi dari 
sebagian tulisan tertentu dalam naskah dan terletak di footer. Informasi tersebut bisa berupa referensi, rekomendasi bacaan lanjutan, dan lain-lain.

n. Nomor Halaman

Nomor

halaman

memudahkan pembaca

mengingat lokasi artikel.

\section{Elemen Visual}

Elemen visual atau gambar yang terdapat pada tata letak buku umumnya mendukung segi materi yang terdapat dalam buku. Yang termasuk dalam kelompok elemen visual adalah semua elemen bukan teks yang terlihat.

a. Foto

Informasi yang diberikan dengan adanya foto sebagai "bukti" keakuratan atas informasi yang disampaikan.

b. Artworks

Segala jenis karya seni yang bukan foto seperti ilustrasi, sketsa, dan lain sebagainya, berfungsi untuk menyajikan informasi lebih akurat.

\section{c. Informational Graphics}

Berupa fakta-fakta dan datadata statistik pendukung materi yang disajikan dalam bentuk grafik, tabel, bagan, peta, dan sebagainya.

d. Garis atau Rules

Di dalam tata letak, garis mempunyai sifat yang fungsional, antara lain membagi suatu area, penyeimbang berat, dan sebagai elemen pengikat sistem desain agar terjaga kesatuannya.

e. Kotak atau Frame

Berisi artikel yang bersifat tambahan dari artikel utama.

\section{f. Inzet}

Elemen visual berukuran kecil yang diletakkan di dalam elemen visual yang lebih besar, berfungsinya memberi informasi pendukung. Inzet kadang juga disertai dengan caption maupun callouts.

\section{g. Point atau Bullets}

Suatu daftar yang mempunyai beberapa baris berurutan ke bawah, biasanya di depan tiap barisnya diberi penanda angka atau poin.

3. Elemen Tidak Terlihat

Elemen yang tidak terlihat ini merupakan kerangka yang berfungsi sebagai acuan penempatan semua elemen tata letak lainnya. Elemen tidak terlihat akan bermanfaat sebagai salah satu pembentuk kesatuan dari keseluruhan tata letak.Sesuai dengan namanya, elemen ini tidak akan terlihat pada hasil cetak.

a. Margin

Margin adalah batas-batas yang menentukan jarak antara pinggir kertas dengan ruang yang akan diisi dengan elemen-elemen tata letak. Berguna untuk mencegah elemen-elemen tersebut tidak 


\begin{abstract}
terlalu jauh kepinggir halaman, karena hal tersebut sangat berisiko terpotongnya elemen pada saat pencetakan. Margin akan memberikan white space di sekitar area teks yang tercetak, sehingga akan menambah keterbacaan teks serta menambah keindahan tata letak. Dua halaman sesudah halaman pertama sebuah buku saat dibuka, harus terlihat menyatu satu dengan yang lain.
\end{abstract}

b. Grid

Grid berfungsi untuk mempermudah untuk menentukan peletakan elemen dan mempertahankan konsistensi serta kesatuan. Grid digunakan sebagai perangkat untuk mempermudah menciptakan sebuah komposisi visual. Tujuan utama dari penggunaan grid dalam desain grafis adalah untuk menciptakan suatu rancangan yang komunikatif dan memuaskan secara estetik. Dengan menggunakan sistem grid, tata letak dapat lebih terstruktur dan terlihat rapi.

Tipografi adalah mengatur teks dalam bentuk yang mudah dibaca dan menarik untuk dipandang. Teks merupakan salah satu elemen terpenting dalam tata letak dan sangat berkaitan dengan tipografi.

Penerapan tipografi harus memperhatikan faktor-faktor berikut ini.

1. Dapat dipahami (Readibility) Tingkat atau level dimana sebuah tulisan dapat dipahami atau dibaca dengan mudah berdasarkan penggunaan kata-kata dalam kalimat.

2. Kejelasan (Clearity)

Menurut David Ogilvy, tipografi yang baik adalah yang "menolong" orang untuk membaca, sebaliknya yang buruk adalah yang "mencegah" orang untuk membaca.

3. Dapat dilihat (Visibility)

Pemakaian tipe huruf harus disesuaikan dengan komposisi yang baik. Peletakan huruf yang terhalang oleh gambar atau warna yang hampir sama dengan latar belakang akan mempersulit pembaca.

4. Keterbacaan (Legibilty)

Keterbacaan memiliki pengertian sebagai kualitas huruf atau naskah dalam tingkat kemudahannya untuk dibaca. Tingkat keterbacaan ini tergantung kepada tampilan bentuk fisik huruf itu sendiri.

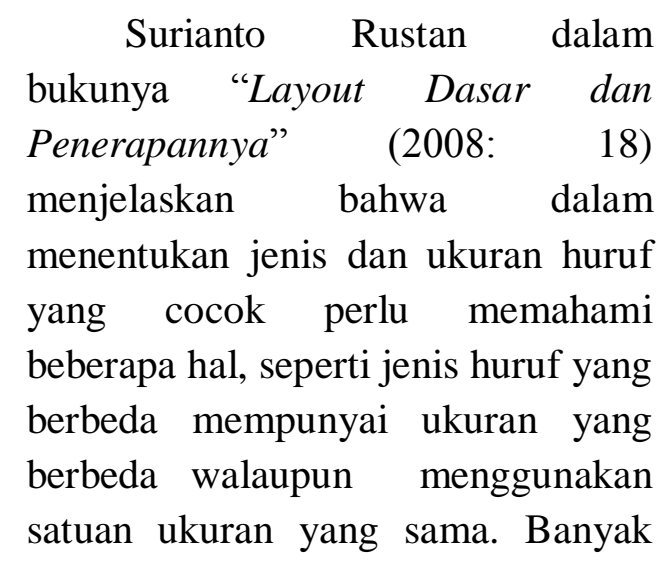


sumber yang menyarankan ukuran huruf untuk bagian isi naskah adalah 9-12 point, sedangkan 14 point ke atas adalah ukuran untuk display type, dan di bawah 9 point adalah ukuran untuk caption.

Dalam menentukan elemenelemen teks ada beberapa pengaturan yang perlu diperhatikan agar teks dapat tersusun dengan baik dan tepat, yaitu:

1 Letter spacing adalah jarak antarhuruf atau karakter pada paragraf.

2 Word spacing adalah jarak antarkata. Word spacing sebaiknya mengikuti letter spacing. Semakin lebar letter spacing, semakin lebar pula pula word spacing-nya.

3 Leading adalah jarak antarbaris, pengukuran jarak antarbaris.

Menurut Pamusuk Eneste dalam bukunya yang berjudul "Buku Pintar Penyuntingan Naskah Edisi Kedua" (2005: 94), gaya selingkung yang dalam bahasa Inggris disebut house style adalah ciri khas yang dimiliki oleh sebuah penerbit dan menjadi identitas penerbit. Hal tersebut berguna untuk membedakan penerbit yang satu dengan yang lainnya. Gaya selingkung bisa saja berubah, tergantung kondisional yang ada pada sebuah penerbit itu sendiri melaui kesepakatan bersama dalam perusahaan. Konsistensi juga sangat penting dalam membangun sebuah gaya selingkung.

Gaya selingkung terbagi menjadi gaya selingkung editorial dan visual. Gaya selingkung editorial mencakup dari segi editorial, seperti ketatabahasaan, ejaan, dan tanda baca sedangkan gaya selingkung visual mencakup dari segi desain, seperti desain sampul, dan tata letak. Gaya selingkung sebuah penerbit juga menentukan hasil tampilan buku yang akan diterbitkan.

Unsur pembentuk gaya selingkung adalah kulit depan, halaman perancis, halaman hak cipta, letak daftar isi, nomor bab, judul bab, informasi tentang pengarang, nomor halaman, dan kulit belakang. Aspek lainnya, seperti dari segi fisik atau grafika, yaitu jenis kertas, ukuran buku, ukuran dan variasi huruf, pengaturan margin, dan penggunaan warna.

\section{METODE PENELITIAN}

Terdapat tiga metode yang digunakan dalam menyusun penelitian ini, yaitu:

1. Metode Studi Pustaka

Penyusunan hasil penelitian ini sebagian besar bersumber dari kajian literatur yang berupa bahan kuliah, buku-buku mengenai desain buku, tata letak buku, gaya selingkung penerbit, produksi penerbitan.

2. Metode Observasi

Metode observasi dilakukan saat melakukan kegiatan Praktik Industri di Penerbit Salemba pada bulan Februari sampai dengan April. Metode ini bertujuan untuk pengumpulan data yang mendukung landasan teori dan pembahasan agar lebih 
memahami mengenai tata letak buku terjemahan di Penerbit Salemba.

3. Metode Wawancara

Metode wawancara dilakukan saat Praktik Industri di Penerbit Salemba dengan Bapak Azhari selaku senior setter, Hilda Yunita selaku setter, dan dosen di kampus, guna mendapatkan informasi mengenai pembahasan hal-hal yang terkait dalam kepentingan penyusunan hasil penelitian ini.

\section{HASIL PENELITIAN DAN PEMBAHASAN}

Naskah buku Komunikasi
Interpersonal merupakan naskah
terjemahan dari buku yang berjudul
"Interpersonal Communication"
yang ditulis oleh Julia T. Wood dan
diterbitkan oleh penerbit Cengage
yang memang sudah bekerjasama
dengan Penerbit Salemba. Naskah
terjemahan memiliki tingkat
kerumitan yang berbeda daripada
naskah lokal, baik dari segi isi
maupun desain. Penerbit Cengage
mengirim naskah dalam bentuk e-file
kepada Penerbit Salemba. Setelah
itu, naskah diterjemahkan oleh
penerjemah, kemudian langsung
dilakukan pembuatan tata letak oleh
desainer tata letak, tidak diedit
terlebih dahulu. Tata letak buku
terjemahan harus sama dengan buku
asli, dari segi struktur, dan desain
isinya. Namun, tetap disesuaikan
dengan gaya selingkung Penerbit
Salemba dan kreativitas desainer tata

letak itu sendiri.

\section{Identitas Buku}

Judul: Komunikasi Interpersonal Penulis : Julia T. Wood

Jenis naskah: Buku Non Fiksi

Jumlah halaman: 634 halaman

Ukuran: $21 \mathrm{~cm}$ x $28 \mathrm{~cm}$

Penggunaan Warna: Full colour (sampul buku) dan hitam-putih (isi)

Pada pembuatan tata letak naskah terjemahan, terdapat bagianbagian dalam buku asli yang merupakan gaya selingkung visual penerbit asli, yang berbeda dengan Penerbit Salemba. Hal tersebut menyebabkan jumlah halaman buku yang sudah diterjemahkan, lebih banyak daripada buku aslinya. Jadi, biaya produksinya pun lebih mahal. Gaya selingkung Penerbit Salemba untuk naskah terjemahan sebagai berikut:

Jenis huruf isi: Minion Pro, Garamond, Book Antiqua

Ukuran huruf isi: $10,5 \mathrm{pt}$ Jenis kertas isi: Book paper 55 gram

Book paper: 50 gram

Art paper: 80 gram dan 100 gram

Ukuran buku :15,5 x $24 \mathrm{~cm}$

$$
\begin{aligned}
& 17 \times 24 \mathrm{~cm} \\
& 19 \times 26 \mathrm{~cm} \\
& 21 \times 28 \mathrm{~cm}
\end{aligned}
$$

\section{Pola Tata Letak}

1. Pengaturan Margin

Margin yang digunakan pada buku terjemahan Komunikasi Interpersonal adalah sebagai berikut:

$\begin{array}{llll}\text { Top } & : 25 \mathrm{~mm} & \text { Bottom } & : 20 \mathrm{~mm} \\ \text { Inside } & : 20 \mathrm{~mm} & \text { Outside } & : 15 \mathrm{~mm}\end{array}$


2. Grid

Grid dalam sebuah tata letak merupakan hal yang penting. Grid berfungsi untuk memudahkan

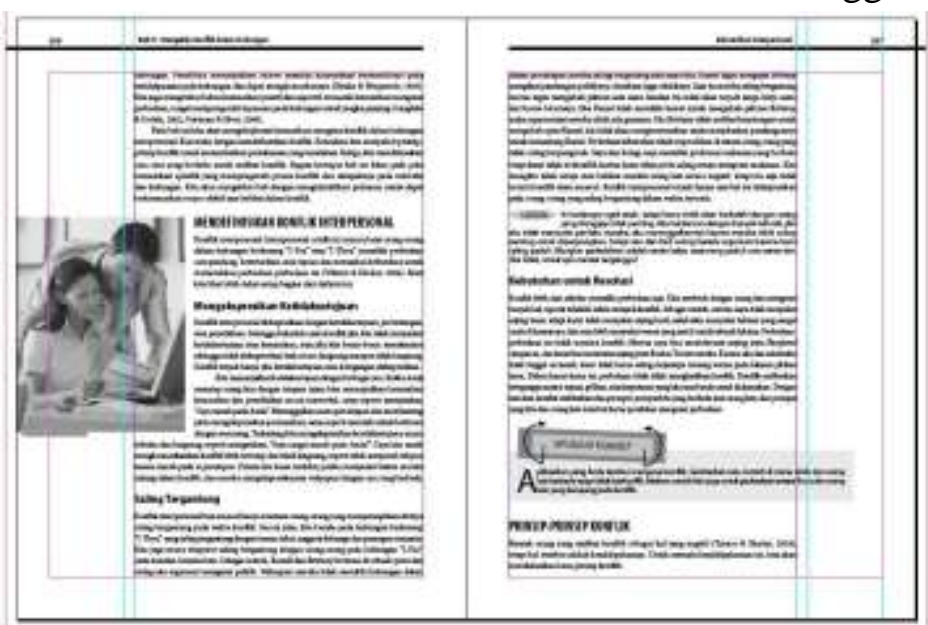

Gambar 3.1 Grid satu kolom dalam buku terjemahan Komunikasi Interpersonal

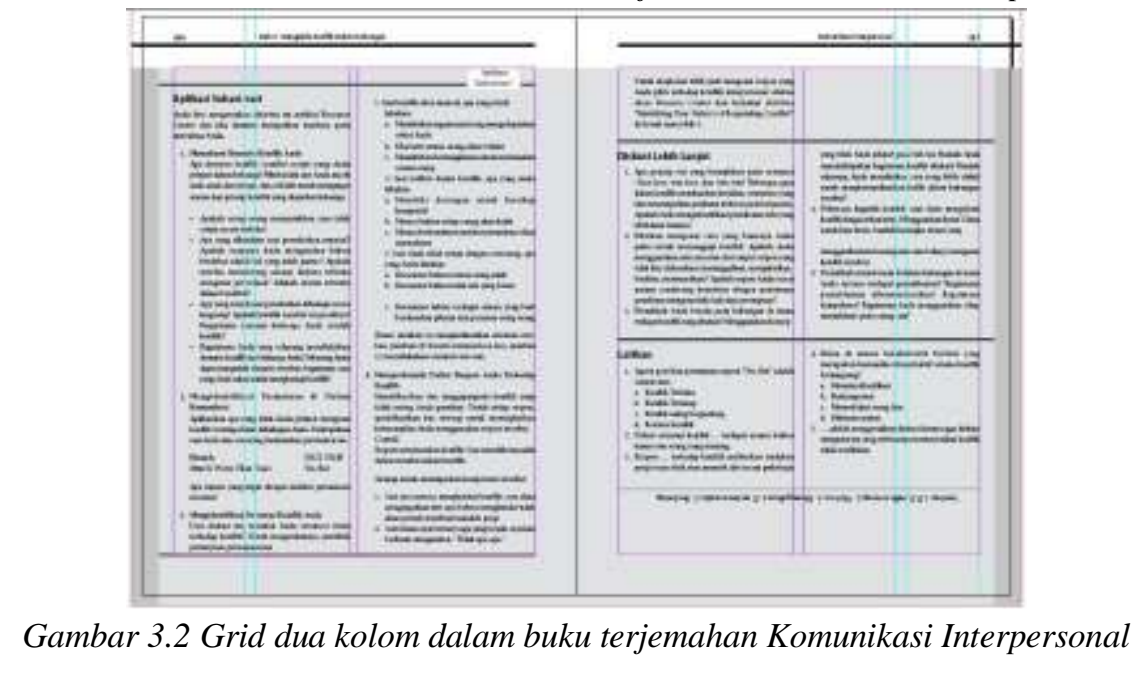

Gambar 3.2 Grid dua kolom dalam buku terjemahan Komunikasi Interpersonal
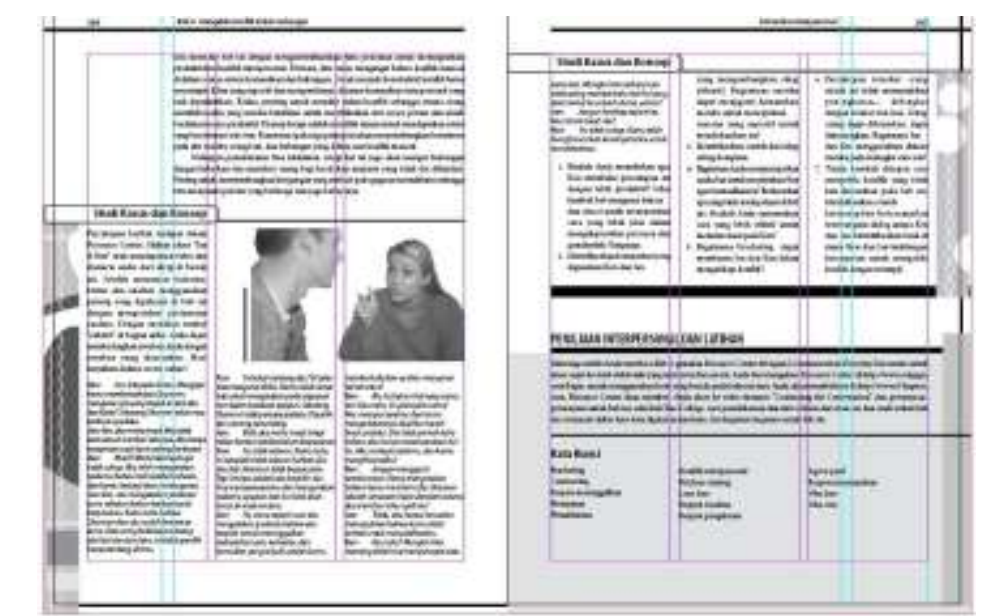

Gambar 3.3 Grid tiga kolom dalam buku terjemahan Komunikasi Interpersonal dalam menata teks dan gambar. Grid dalam naskah terjemahan Komunikasi Interpersonal memiliki satu hingga tiga kolom. 
3. Alignment

Dalam naskah terjemahan Komunikasi Interpersonal, alignment yang digunakan adalah rata kiri dan rata kiri-kanan. Rata kiri digunakan untuk teks ornamen desain dan rata kiri digunakan untuk beberapa ornamen desain sedangkan rata kiri-kanan digunakan untuk isi.

4. Paragraph Style

Paragraph style sangat penting perannya dalam sebuah tata letak karena berfungsi untuk mengelompokkan sebuah paragraf yang terdiri atas jenis dan ukuran font, indent, spacing, dan sebagainya. Semua style tersebut sudah di-setting terlebih dahulu, agar dapat menggunakannya secara otomatis dan cepat.

5. Perangkat Lunak dan Aplikasi Pendukung

Dalam pembuatan tata letak naskah terjemahan Komunikasi Interpersonal menggunakan perangkat lunak yang berfungsi untuk proses pembuatan tata letak tersebut. Perangkat lunak yang digunakan Penerbit Salemba dalam pembuatan tata letak buku terjemahan Komunikasi Interpersonal adalah Microsoft Word 2007, Adobe Indesign CS3, Adobe Photoshop CS3, dan Portable Document Format (PDF).

a. Microsoft Word 2007

Microsoft Word adalah perangkat lunak pengolah kata (word processor) andalan Microsoft. Setelah menjadi bagian dari Microsoft Office
System 2003 dan 2007 diberi nama Microsoft Office Word. Dalam pembuatan tata letak naskah terjemahan, berawal dari naskah mentah yang sudah diterjemahkan oleh penerjemah dalam bentuk Ms. Word. Setelah itu diolah menggunakan aplikasi pendukung seperti Adobe Indesign CS3 dan Adobe Photoshop CS3.

b. Adobe Indesign CS3

Adobe Indesign merupakan salah satu program page layout yang terkenal dan cukup banyak penggunanya. Hal tersebut dikarenakan kemudahan dalam membuat tata letak di aplikasi ini. Dalam buku "Pengantar Desain Komunikasi Visual" (2006 : 273) Adi Kusrianto menyebutkan bahwa Adobe Indesign dinobatkan sebagai Standar Industri Percetakan di berbagai negara, seperti halnya Photoshop yang lebih dulu memimpin di dunia cetak maupun website. Banyak kelebihan yang dimiliki Adobe Indesign dibanding dengan perangkat lunak lainnya, diantaranya kenyamanan dalam membuat desain dengan multiple pages design (tata letak dalam beberapa halaman) dengan adanya fungsi master pages.

c. Adobe Photoshop CS3

Adobe Photoshop adalah perangkat lunak buatan Adobe 
Systems yang dikhususkan untuk pengeditan foto atau gambar dam pembuatan efek. Dalam pembuatan tata letak naskah terjemahan, Photoshop sangat diperlukan untuk mengolah gambar hasil scan agar mendapatkan hasil gambar yang baik.

d. Portable Document Format (PDF)

PDF adalah sebuah format berkas yang dibuat Adobe System pada tahun 1993 untuk keperluan pertukaran dokumen dua dimensi yang meliputi teks, huruf, dan grafik vektor dua dimensi. Format file ini digunakan oleh Adobe Acrobat dan dapat digunakan oleh grafik berbasis pixel maupun vektor. Format file ini menyimpan gambar dengan mode warna. RGB dan CMYK. Penggunaan PDF di Penerbit Salemba dalam proses membuat tata letak buku terjemahan berguna untuk pengoreksian yang sudah dibuat di Adobe Indesign. Kegunaan lain adalah naskah yang sudah di book di Indesign, kemudian dijadikan format PDF sebelum akhirnya dicetak.

6. Sistematika Buku Terjemahan Komunikasi Interpersonal

Dalam sistematika buku, terlihat pula pembuatan tata letak pada buku terjemahan Komunikasi Interpersonal dan kaitannya berdasarkan gaya selingkung Penerbit Salemba itu sendiri.

a. Prelims

Prelims atau bagian pembuka pada naskah Komunikasi Interpersonal terdiri dari halaman prancis, halaman hak cipta, daftar isi singkat, daftar isi, kata pengantar, ucapan terimakasih, tentang penulis, pengantar.

(1) Halaman Prancis

Halaman prancis hanya menampilkan judul tanpa diikuti nama pengarang dan logo penerbit, sama seperti buku pada umumnya.

(2) Halaman Hak Cipta

Halaman hak cipta berada setelah halaman prancis. Halaman ini terdapat larangan pengutipan tanpa izin. Bunyi larangan pengutipan tanpa izin seperti berikut:

"Dilarang mengutip atau memperbanyak sebagian atau seluruh buku ini tanpa izin tertulis dari penerbit."

(3) Daftar Isi

Daftar isi dalam naskah ini terdiri dari daftar isi singkat dan daftar isi. Daftar isi singkat berisi bab-bab nya saja. Kalau daftar isi berisi dari mulai prelims, isi (bab dan subbab) hingga postlims. Jenis dan 
ukuran huruf tulisan

daftar isi yaitu Lucida

Calligraphy, italic, 20 pt.

Sedangkan untuk bagian-bagian daftar isi menggunakan jenis dan ukuran huruf nya sesuai dengan isi. Karena daftar isi sudah otomatis sesuai dengan paragraph style.

(4) Kata Pengantar

Kata pengantar ini ditulis oleh penulis buku dan berada setelah halaman daftar isi. Kata pengantar berisi latar belakang dibuatnya buku serta memaparkan kelebihan yang ada di dalam buku. Jenis dan ukuran huruf tulisan kata pengantar sama dengan daftar isi, yaitu Lucida Calligraphy, italic, 20 pt. Sedangkan untuk isi nya menggunakan jenis dan ukuran huruf Minion Pro, regular, 10, 5 pt.

(5) Ucapan Terimakasih

Ucapan terimakasih penulis untuk pihakpihak yang telah membantu tersusunnya buku tersebut dan berada di dalam kata pengantar. Letaknya berada di dalam kata pengantar.

(6) Tentang Penulis

Berisi tentang biografi penulis dan juga berada di dalam kata pengantar.

b. Isi
Bagian isi terdiri atas pengantar dan bab 1 sampai dengan bab 12. Penomoran halaman memakai angka arab dan dimulai dari bagian pengantar.

(1) $\mathrm{Bab}$

Bab yang dibuat haruslah bab demi bab, artinya memiliki file masing-masing setiap babnya. Bertujuan untuk memudahkan jika terjadi perubahan dalam pembuatan tata letak, lebih mudah diperbaiki. Pada naskah Komunikasi Interpersonal, halaman bab berisi nomor bab dan judul bab, kutipan, dan gambar. Terpisah dari isi bab dan selalu berada di halaman bagian kanan. Jika halaman terakhir dari bab sebelumnya berada di halaman bagian kanan, halaman bagian kiri harus dikosongkan, dan ini termasuk dari gaya selingkung Penerbit Salemba sedangkan pada buku asli, halaman bab tidak selalu berada di bagian kanan, terkadang juga berada di bagian kiri.

Jadi jika halaman terakhir pada bab sebelumnya berada di 
sebelah kanan, lembar

selanjutnya yaitu

lembar kiri tidak perlu

dikosongkan. Hal

tersebut yang

menyebabkan buku

asli jumlah halaman

lebih sedikit daripada

buku terjemahan.

Nomor bab

menggukan huruf

Arab. Nomor bab

diletakkan pada bagian

pojok kanan atas dan

judul bab berada di

tengah, di bawahnya

terdapat kutipan dan

gambar. Judul bab

ditulis dengan huruf

kapital. Jenis huruf:

Myriad Pro. Ukuran

huruf : 24 pt.

Alignment: Rata kiri

$\begin{array}{ll}\text { Dalam } & \text { bukunya } \\ \text { yang } & \text { berjudul }\end{array}$

"Menjadi Desainer

Layout Andal

Menggunakan Adobe

Indesign CS 3"

(2007:173), Edi S.

Mulyanta menuliskan

bahwa file book adalah

kumpulan dari

dokumen yang saling

berbagi pakai style.

Pengaturan nomor

halaman dapat

dilakukan pada

dokumen yang ada

pada file book ini,

mencetak dokumen,

serta mengekspor ke
PDF. Style acuan

adalah dokumen

pertama di dalam

sebuah book, akan

tetapi dapat memilih

style acuan yang baru

secara bebas. Style

acuan digunakan

sebagai dasar untuk

menentukan elemen-

elemen paragraf yang

akan disalin ke

dokumem lain.

(2) Subbab

Subbab ditulis

menggunakan huruf

kapital. Jenis huruf:

Myriad Pro. Ukuran

huruf: 18 pt. Alignment

: Rata kiri

(3) Teks

Teks untuk isi dibuat

pada area text frame

satu kolom yang

ditentukan berdasarkan

lebar dan tinggi

margin. Namun di

akhir setiap bab

terdapat dua sampai

tiga kolom. Naskah

terjemahan memiliki

cukup banyak ornamen

desain di dalamnya

dan letaknya terkadang

melebihi margin.

Tetapi tidak melewati batas area cetak. Jenis

huruf: Minion Pro.

Ukuran huruf: $10 \mathrm{pt}$.

Alignment: Rata kiri.

Penggunaan jenis

dan ukuran huruf 


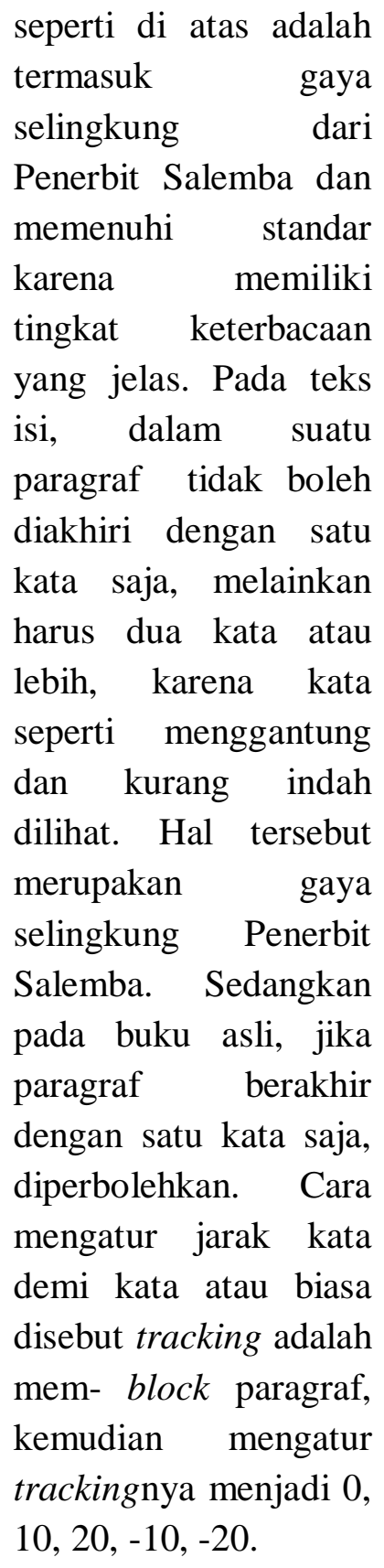

(4) Nomor Halaman

Nomor

$\begin{array}{lr}\begin{array}{lr}\text { halaman } \\ \text { digunakan }\end{array} & \begin{array}{r}\text { yang } \\ \text { untuk }\end{array} \\ \text { bagian prelims } & \text { adalah } \\ \text { huruf } & \text { Romawi. } \\ \text { Sedangkan } & \text { nomor } \\ \text { halaman } & \text { yang } \\ \text { digunakan } & \text { untuk } \\ \text { bagian } & \text { isi } \\ \text { menggunakan } & \text { huruf }\end{array}$

Arab dan diletakkan di bagian pojok atas di setiap halamannnya. Nomor halaman di bagian kanan terdapat judul bab dan bagian kiri terdapat judul buku yang disebut juga dengan running head. Itu termasuk gaya selingkung dari Penerbit Salemba. Sedangkan pada buku asli, nomor halaman di bagian kiri terdapat nomor bab saja dan bagian kanan terdapat judul bab. Pada bagian ini, dibuat dengan menggunakan master. Master bertujuan agar memudahkan pembuatan tata letak. Agar dapat dikerjakan secara otomatis. Selain mempermudah, hal tersebut juga menghemat waktu.

(5) Keterangan (Callouts)

Keterangan

$\begin{array}{lr}\text { singkat } & \text { sebagai } \\ \text { informasi } & \text { yang } \\ \text { menyertai } & \text { elemen } \\ \text { visual atau } & \text { gambar. } \\ \text { Jenis dan ukuran } & \text { ullouts berbeda dari } \\ \text { calla } & \text { teks isi. Jenis dan } \\ \text { ukuran hurufnya yaitu } \\ \text { Myriad Pro, regular, } \\ 10 \text { pt. }\end{array}$

c. Postlims

Postlims atau bagian penutup 
pada naskah Komunikasi
Interpersonal terdiri dari
epilog, glosarium, referensi,
indeks.

(1) Epilog

$\begin{array}{lr}\text { Epilog } & \text { adalah } \\ \text { rangkuman } & \text { singkat } \\ \text { tentang } & \text { naskah }\end{array}$

Komunikasi

Interpersonal. Di

dalam epilog juga

terdapat bagian

penutup yang berisi

tentang kesan

mengenai pentingnya

bahasan yang terdapat

di dalam naskah

terjemahan

Komunikasi

Interpersonal.

(2) Glosarium

Glosarium adalah

kamus dalam bentuk ringkas dan disusun berdasarkan alfabetis.

Berfungsi juga untuk membantu pembaca dalam memahami isi buku.

(3) Referensi

Referensi adalah sumber yang menjadi acuan untuk bagi para pembaca. Acuan tersebut biasanya berisi nama penulis dan bukunya. Desain referensi sama dengan glosarium.

(4) Indeks

Daftar kata atau istilah penting yang terdapat pada bagian akhir buku dan tersusun menurut abjad yang memberikan informasi mengenai halaman tempat kata atau istilah itu ditemukan. Indeks buku sebelum era komputerisasi

Desktop Publishing, merupakan pekerjaan yang paling berat dalam menyusun sebuah publikasi karena membutuhkan ketelitian yang sangat tinggi serta ketekununan yang luar biasa. Indeks terkadang merupakan tujuan pertama pembaca untuk mencari informasi awal, sehingga pembuatan indeks harus terstrukur dengan baik dan lengkap agar memudahkan

pembaca. Setiap aplikasi baik pengolah data maupun tata letak akan selalu menyertakan tool pembuatan indeks yang cukup mudah penggunaannya serta penyusunannya.

Pembuatan

indeks dapat 


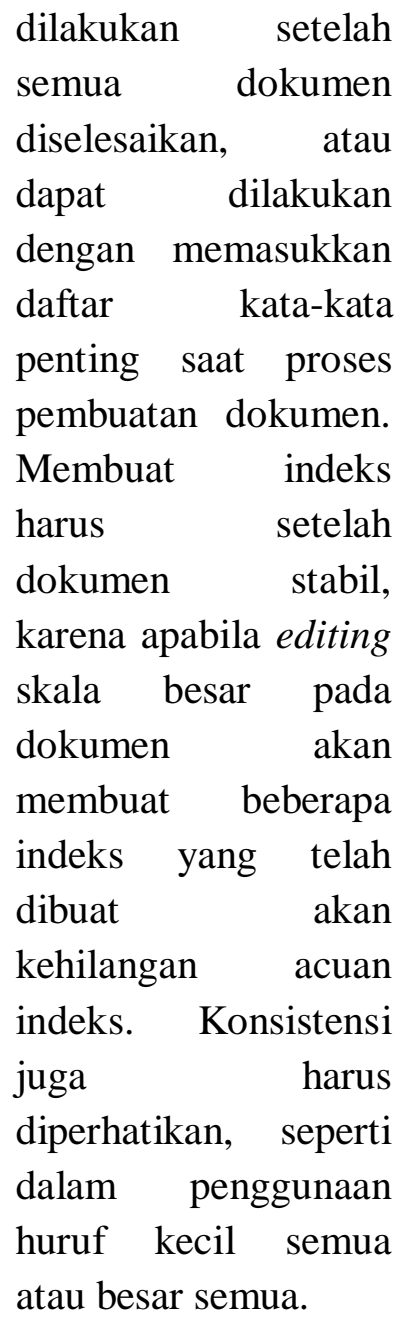

\section{Pembahasan}

\section{Proses Pembuatan Buku}

Proses pembuatan buku terjemahan

Komunikasi

Interpersonal tidak melalui proses yang semestinya. Naskah mentah dalam bentuk e-file dikirim oleh Penerbit Cengage ke Penerbit Salemba, kemudian diterjemahkan oleh penerjemah dan langsung dilakukan pembuatan tata letak, tidak diedit terlebih dahulu. Akibatnya desainer dan editor memiliki kesulitan dalam pembuatan buku ini. Sebaiknya, sebuah buku melalui proses yang semestinya, yaitu naskah mentah diedit terlebih dahulu oleh editor, kemudian dilakukan
pembuatan tata letak oleh desainer.
Pembuatan tata letak dilaksanakan pada bulan Februari sampai dengan April dan tidak deadline. Hal tersebut yang membuat prosesnya tidak semestinya. Editor mengerjakan naskah-naskah yang deadline terlebih dahulu, sehingga naskah yang tidak deadline, dilakukan setelah pembuatan tata letak.

\section{Kendala Pembuatan Tata Letak dan Cara Mengatasinya}

Dalam pembuatan tata letak buku Komunikasi Interpersonal terdapat beberapa kendala, yaitu data e-file yang kurang lengkap, perubahan kata dalam naskah yang sudah disetting, membuat ornamenornamen desain, kualitas gambar atau foto rendah dikarenakan hasil dari scan, dan menangani missing font.

1. Data E-file Kurang Lengkap

Masalah utama dalam naskah terjemahan adalah ketersediaan data $e$-file yang kurang lengkap. E-file naskah Komunikasi Interpersonal hanya mencakup teks saja. Gambar maupun foto dan ornamen desain tidak tersedia. Terdapat beberapa bagian naskah yang belum diterjemahkan dengan baik. Kendala ini adalah yang utama dari pembuatan tata letak naskah terjemahan karena hal ini membingungkan.

Desainer tata letak harus menyesuaikan naskah yang ada di Microsoft Word dengan buku 
aslinya yang berbahasa Inggris. Terlebih naskah langsung di setting tanpa diedit terlebih dahulu. Jadi, banyak terdapat kesalahan dan hal tersebut menyulitkan desainer tata letak maupun editor. Hal tersebut dapat memakan waktu yang lebih lama. Cara mengatasinya adalah dengan cara memberikan note pada buku asli dan di Adobe Indesign. Hal tersebut agar memudahkan editor bahasa untuk mengedit dan tidak terlalu membuang waktu dalam tahap pembuatan tata letak.

2. Perubahan Kata

Perubahan satu kata saja dalam suatu naskah yang sudah disetting dapat mengubah susunan kata dalam beberapa baris. Perubahan ini seperti menghilangkan, menambah, maupun mengubah kata tersebut yang lebar katanya belum tentu sama. Terlebih naskah yang baru diterjemahkan, langsung di layout dan belum diedit. Jadi pasti banyak kata dan kalimat yang berubah, dan setter atau desainer tata letak harus benar-benar jeli melihat perubahan tersebut, karena jika tidak tentu saja akan merusak keindahan buku.

3. Membuat Ornamen Desain

Membuat ornamen-ornamen desain yang lebih kurang mirip dengan buku aslinya, tentu memiliki tantangan tersendiri. Desainer tata letak dituntut membuatnya semirip mungkin tetapi tetap harus dapat berimajinasi menuangkan ide-ide dengan kreatifitas desain yang dibuatnya.

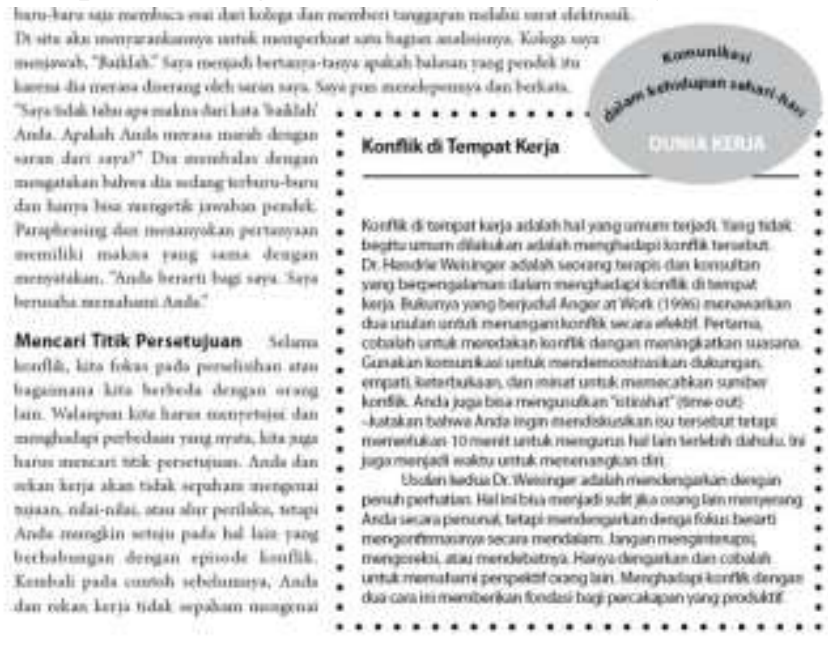

Gambar 3.23 Salah satu contoh ornamen desain

Ornamen desain terdapat hampir di setiap halaman dan tidak mungkin jika setiap ornamen dibuat ulang atau di copy paste. Cara mengatasinya adalah ornamen-ornamen tersebut di group dengan cara block ornamen desain tersebut, lalu tekan ctrl+G, setelah itu disimpan di Library. Jadi ornamen-ornamen tersebut hanya perlu di drag jika ingin ditamnpilkan. Hanya perlu diedit 
sedikit karena tidak semua ornamen sama. Ornamen-ornamen desain tersebut juga harus menggunakan text wrap, agar terdapat jarak antara ornamen desain dengan text box. Text wrap yang digunakan disesuaikan dengan letak dari ornamen desain tersebut.

4. Kualitas Gambar Rendah

Naskah terjemahan Komunikasi Interpersonal tidak disertai data $e$ file yang lengkap seperti gambar atau foto. Oleh karena itu gambar atau foto harus di scan terlebih dahulu dan kemudian diedit di Photoshop, dengan meningkatkan resolusi gambar menjadi 300 pxl, mengubah menjadi hitam putih, mengatur level, dan curve-nya.

\section{Menangani Missing Font}

Saat membuka atau melakukan place dokumen, dimana di dalamnya termasuk bentuk font yang tidak terpasang di dalam sistem, maka Indesign akan memberikan peringatan tentang tidak tersedianya font tersebut. Hal inilah yang sering disebut missing font. Untuk menanganinya, dapat dilakukan dengan cara selalu menyertakan font yang digunakan, saat mengirimkan file ke tempat lain yang mungkin mempunyai sistem font yang berlainan dan install font tersebut.

6. Menangani Editing dan Updating Daftar Isi

Daftar isi merupakan gambaran dasar secara keseluruhan dalam sebuah dokumen. Harus menggunakan paragraph style secara konsisten pada keseluruhan book. Hindari membuat dokumen dengan style yang mempunyai nama yang sama, tetapi mempunyai definisi yang berlainan. Jika melakukan beberapa perubahan seperti penomoran, jenis huruf, ukuran huruf, dan sebagainya, harus dilakukan proses updating atau perbaharuan. Jika daftar isi memerlukan beberapa editing, lakukan editing pada dokumen asli, jangan melakukan editing pada daftar isi yang sudah ada. Cara melakukan updating daftar isi adalah untuk mengubah format judul pada daftar isi, isi teks, atau nomor halaman, edit di paragraph style. Pilih menu Layout > Update Table of Contents.

\section{PENUTUP}

Simpulan dalam penelitian ini adalah sebagai berikut.

1. Pembuatan tata letak buku terjemahan dilakukan dengan menggunakan aplikasi-aplikasi pendukung, seperti Microsoft Word 2007, Adobe Indesign CS3, Adobe Photoshop CS3, dan PDF. Dalam sistematika buku tersebut, terlihat pula pembuatan tata letaknya yang berdasarkan gaya selingkung Penerbit Salemba.

2. Terdapat beberapa kendala dalam pembuatan tata letak buku terjemahan, seperti data e-file kurang lengkap, perubahan kata dalam naskah yang sudah di 
setting, membuat ornamenornamen desain, kualitas gambar rendah, dan terjadi missing font. Dalam mengatasi kendala dan masalah yang ditemukan dalam pembuatan buku terjemahan, penulis dituntut untuk dapat fleksibel dan aktif untuk dapat mengetahui bagaimana membuat tata letak yang baik dan memang sesuai dengan gaya selingkung penerbit. Mendapat pengetahuan tambahan mengenai gaya selingkung penerbit dalam pembuatan tata letak.

\section{DAFTAR RUJUKAN}

Departemen Pendidikan Nasional. 2008. Kamus Besar Bahasa Indonesia Edisi Keempat. Jakarta: Gramedia Pustaka Utama.

Eneste, Pamusuk. 2005.

Penyuntingan Naskah Edisi Kedua. Jakarta: Gramedia
Pustaka Utama.

Haslam, Andrew. 2006. Book

Design. UK: Laurence King

Publishing

Kusrianto, Adi. 2007. Pengantar

Desain Komunikasi Visual.

Yogyakarta: Penerbit Andi.

Mulyanta, Edi.S. 2007. Menjadi

Desainer Andal Menggunakan

Adobe Indesign CS3.

Yogyakarta: Penerbit Andi.

Purwanto, Bb. 2006. Desain Grafika

Pengantar Tata Letak dan

Tipografi. Jakarta: LPMG-

ATG Trisakti.

Rustan, Surianto. 2010. Layout

Dasar dan Perapannya Edisi

2009. Jakarta: Gramedia

Pustaka Utama.

Wb, Iyan. 2007. Anatomi Buku.

Bandung: Kolbu. 